ISSN : 2722-7820 (Online)

Point of View Research Accounting and Auditing

https://journal.accountingpointofview.id/index.php/povraa

\title{
Environmental audit analysis to support Sustainability Development
}

\author{
Desy Fitria Ningsih $\uparrow 1$, Asriani Junaid 2, Mursalim Mursalim 3
}

Universitas Muslim Indonesia, Urip Sumohardjo KM.5 Street, Panaikang, Makassar, 90231, South Sulawesi, Indonesia

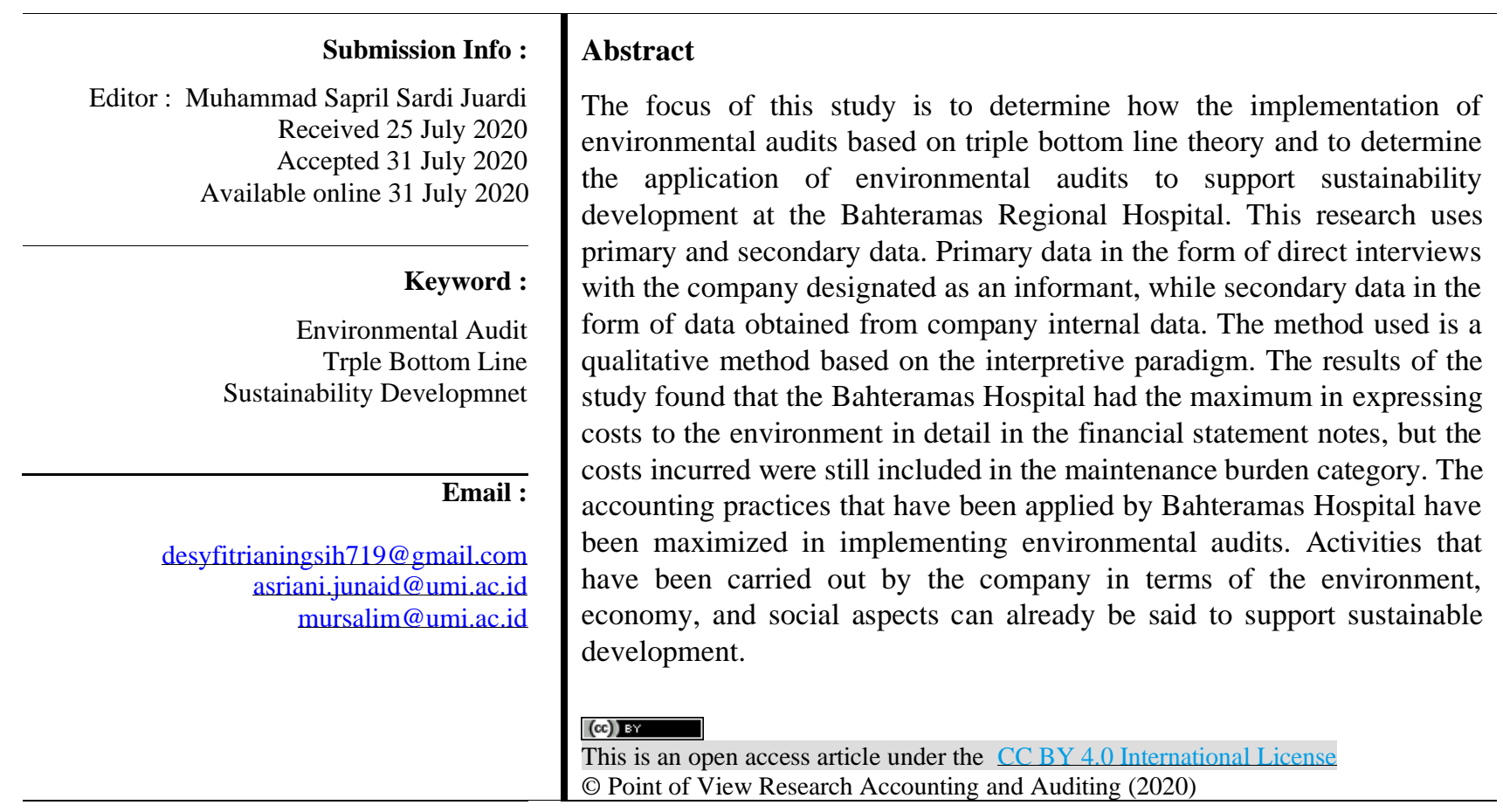

\section{Introduction}

Economic activity at this time directly or indirectly has become a factor causing global warnings (Ja'far \& Kartikasari, 2009). Various issues related to the environment such as global warming and industrial activities have also caused a direct impact on the surrounding environment and have come to the attention of today's modern economists (McCright \& Dunlap, 2000; York \& Rosa, 2003; Hertwich, 2005). Environmental conditions are life problems that are quite worrying and have occurred throughout the world, including in Indonesia (McCright \& Dunlap, 2000; Lorenzoni \& Pidgeon, 2006; Kusminingrum, 2008; Murdifin et al., 2019). Companies and other business organizations usually only apply the concept of profit maximization (one of the concepts adopted by capitalists), but at the same time they violate the consensus and the principles of profit maximization itself (Suartana, 2010). This concept also encourages companies to continue to find ways to conduct efficient production (Kocka, 2015). Impacts of violations of these principles include, among others, a lack of attention to environmental management programs, low environmental performance and low corporate

\footnotetext{
$†$ Corresponding author. Desy Fitria Ningsih

Email address: desyfitrianingsih@719@gmail.com
} 
interest in environmental conservation (Omer, 2008; Kosajan, et al., 2018; Du, 2018).

Sustainable development is development that balances ecological or economic and social aspects (Pettman \& Herath, 2005; Sari \& Hadiprajitno, 2013; Damayanti \& Pentiana, 2013). One important aspect of sustainable development is that ecological / environmental aspects will be fulfilled if the company implements environmental accounting management that is proven to be able to improve environmental performance (Burhany \& Nurniah, 2014). Every industrial development carried out by the company is directed to pay attention to aspects of the surrounding environment in order to prevent pollution or damage to the environment and sustainable natural resources and carrying capacity is not disturbed (Musyarofah, 2013). The main principle in building to meet the needs of the present without compromising the needs of future generations (Burhany \& Nurniah, 2014). An understanding of environmental issues will direct the company in its policies, especially related to environmental safety (Astuti \& Nugroho, 2016). Gray's research (2010) states that accounting and social and environmental sustainability reporting so far have not really rooted in the concepts of sustainability (ecological) and ecological, reporting and accounting concepts that exist only as a complement and legitimator of the company, that the company does have social title and environment are only "clothes" and not "hearts" of the company.

John Elkington through his book "Cannibals with Fork, Triple Bottom Line of Twentieth Century Business" developed the concept of Triple Bottom Line in 1997 with the term economic prosperity, environmental quality, and social justice. Elingkton proposed his view that companies that want to survive must pay attention to "3Ps". In addition to pursuing profits, companies must also pay attention and be involved in meeting the welfare of the community and actively contributing to the preservation of the environment (planet). Profit itself is basically additional income that can be used to ensure the survival of the company, while activities that can be carried out to increase profits consist of increasing productivity and cost efficiency, so that the company will be more competitive in providing maximum added value (Elkington, 1998; Elkington, 2013; Ekuwueme et al., 2013; Harahap et al., 2016). The Triple Bottom Line then illustrates that there is no selfishness in business practices, businesspeople must still be responsible for the environment and nature and the community is not concerned with personal matters. The idea of economic and social will produce a fair word or a balanced environment, a combination of social and environmental will produce a livable word or a viable environment, while the combination of environment and economy will produce an environment with vibrant economic growth so that if all three are combined it will generate sustainability development or sustainable company development (Yanti \& Rasmini, 2015).

Recognizing the position of the community as important company stakeholders, that their support is needed for the existence, sustainability and development of the company, as an integral part of the environmental community, the company needs to be committed to working to provide the best benefits for them. It must be realized that the company's operations have the potential to impact on society, so the company needs to make every effort related to community needs. The environment is everything related to all aspects of human life (Elkington, 1998). The relationship between humans and the environment is a causal relationship, that if humans protect the environment, the environment will provide them with benefits (Elkington, 1998). So the company must imply Triple bottom line theory so that the company must prioritize the interests of all parties involved and affected by the activities of the company rather than only the interests of shareholders (Neviana, 2010). Companies must see a new side of corporate responsibility as a result of the impact of company performance so that the existence of the company can survive and be long-term and sustainable compared to only looking for profits or profits that are short-term (Astuti, 2016).

Legitimacy theory is a theory that is often used especially in relation to the social and environmental accounting fields. Legitimacy is considered important for the company because people's legitimacy to the company is a strategic factor for the company's future development (Agustina, 2016). This theory has offered a real perspective on the community's voluntary recognition of a company through an implied social contract between social institutions and the community (Badjuri, 2011; Widiawati \& Raharja, 2012). This will have an impact on the company to continue to strive to ensure that its operational activities are in accordance with existing norms in the community or environment where it is located (Deegan, 2004). In addition, organizational legitimacy can be seen as something given by the community to the company and as something that is desired or sought by the company from the community that will be a potential benefit or resource for survival (Mia $\&$ 
Al Mamun, 2011).

Government or private organizations in their operations cause damage to ecosystems due to the presence of company production waste which naturally requires allocation of special handling costs. Like the hospital, in addition to having medical skills, it must also manage the waste produced. This concept still sounds new to hospitals because so far this concept has only been applied to business entities that are profit oriented (private). Even though the hospital is also a unit that is inseparable from social environmental problems. However, until now the government's efforts to meet the community's need for health have not been able to meet the expectations of the community. Many people who complain and feel dissatisfied with the services provided by the Hospital both in terms of examinations that are not given enough attention by health workers, length of service time, staff skills, facilities / facilities, cleanliness, and waiting times that get services. The ideal service conditions are realistic and in accordance with the expectations of the community it is very difficult to be realized in government. The concept of an environmentally friendly hospital is more directed at the use of water that is effective and efficient, the use of electricity efficiently, and the management of liquid waste that is environmentally sound (Aminah \& Noviani, 2014). Hospital waste management mechanism must be of particular concern through systematic management so as not to cause negative impacts such as air pollution, production waste, social inequality, etc. and this kind of impact is called Externality. Types of medical waste include radioactive waste, infectious waste, pathology and anatonim, cytotoxic waste, chemical and pharmaceutical waste (Windasari \& Harimurti, 2011).

In this study, the Bahteramas Regional General Hospital was chosen by researchers as a place of research because the Hospital is a Rheumatology Hospital with a broad and important scope of tasks and service functions. The issue of hospital environmental management is one of the efforts to create a clean, comfortable and hygienic Hospital environment in order to minimize environmental costs. Based on the poor environmental conditions, it is possible for service companies to disclose environmental activities that are closely related to medical and non-medical waste as an additional report completing the required financial statements, but the tendency that occurs is that companies very rarely put their environmental activities into additional reports presented together in the company's financial statements. The development of companies or organizations either government or private that in the implementation of its operations cause damage to the ecosystem due to the production of company waste that is found to require allocation of special handling costs (Aminah \& Noviyani, 2014). From this as a company that is in direct contact with natural resources, research is carried out to see the extent of the implementation of environmental accounting that has been set by the company in this case an environmental audit analysis to support sustainability development.

This research is quite important to do because currently there is a need for good management efforts from a hospital. If the waste management system is not carried out properly, the potential for hospitals to pollute the environment is quite large. Theoretically, this research is expected to perfect the triple bottom line theory consisting of Profit, Planet, and People. This research is expected to be an input to Bahteramas Regional Hospital in conducting an environmental improvement by implementing an environmental audit looking at the triple bottom line theory (profit, nature, and humans) and realizing sustainable development by linking the company's economic interests and environmental preservation.

\section{Research Method}

This type of research is qualitative research based on interpretive paradigms that try to construct reality and understand the meaning of a process, event and authenticity. This research uses ethnometodology method whose main purpose is to study how members of the community during social interactions take place, making sense of indexical expressions. This research will explain how the application of environmental audit analysis to support sustainability development. This research was conducted in the city of Kendari, especially in the Hospital of the Bahteramas General Hospital, Kendari. Primary data obtained by field surveys through interviews with informants (medical staff, administrative staff and the surrounding community). Secondary data Research informants are considered sufficiently capable and feasible to provide the information needed in this study. To get key information using snowball sampling (Moleong, 2004). The data analysis method used in this research is ethnometodology which will analyze and interpret information obtained from actors based 
on their interpretation of a phenomenon. The focus of the study of ethnometodology is not just "people" as a single entity, but as a member or part of a broader external structure, for example society or community. So the interview is not just to find out answers to questions but rules or structures that make the individual or person produce these actions or answers. The stages of data collection are done by collecting data, reducing data, drawing conclusions are reduced and processed and then presented in a table or graphical format so that it is easy to understand. The final stage is drawing conclusions. This conclusion is drawn after the interpretation of the data on the data that has been presented previously. Data interpretation is the process of interpreting or understanding the meaning of a series of data that has been presented previously and expressed in the form of text or narration. Interpretation of data presented objectively in accordance with existing data or facts, so that research results can be found and conclusions can be drawn (Moleong, 2004).

\section{Result and Discussion}

Result

Description of Application of Environmental Audit Based on Triple Bottom Line Theory

The hospital has a very important role to the community and its environment, so that each of its activities will have an impact on the environment and surrounding communities. The hospital has tried to handle the environment that has arisen from its activities. As said by Mr. DH in the Sanitation Installation section.

Mr. DH "The environmental audit at this hospital is limited to Proper. Proper is a company performance rating assessment program developed by the Ministry of Environment, to encourage hospitals to improve environmental management. Proper assesses from the generator set, air pollution, water pollution and environmental pollution".

Mr. DH "With an Accreditation assessment at the Hospital, the Hospital's activities do not have an impact on the surrounding environment, because the Accreditation assessment covers all activities from solid waste, liquid waste, and gas, even patients included in the assessment. if for proper assessment it is more limited than accreditation".

From this statement it can be seen that the Hospital has tried to pay attention to its environment. Various efforts have been made by the Bahteramas Hospital in carrying out its activities, in order to have a good impact on the environment, social and profit of the Hospital. Based on observations that have been made known that the Bahteramas Hospital has taken good care of its environment this is known by the results of the Accreditation assessment, where the results of the accreditation assessment make the Bahteramas Hospital a hospital with plenary accreditation ( 5 star). Bahteramas Hospital to further improve in protecting the hospital environment all medical teams are emphasized to protect their environment. This was also said by Ms.T in the medical department.

Ms.T "We at the hospital really have to take care of the environment because it is already the hospital standard, and if we are in the room we must educate the patient and the patient's family to inform the mechanism of placing infectious and non-infectious waste, and it is our duty to accept new patients to inform patients and families. And specifically for the medical team, we always have special training, and every day there are officers from the PPI to supervise the compliance of medical officers and patients themselves in complying with hospital regulations for garbage disposal. If there are medical officers who do not comply with the procedure, they will be sanctioned by giving a direct warning from the PPI".

Based on observations made by researchers that the Bahteramas Hospital has indeed provided special officers to monitor the medical in compliance with regulations to protect the hospital environment. Bahteramas Hospital in carrying out its activities has become an obligation to pay attention to environmental preservation, social, and hospital profits in order to remain sustainable.

Environmental audits are reviewed from people

People in the case of a hospital are defined as the public, of course, a hospital must pay attention to the surrounding environment in accordance with the theory of legitimacy that a company in which it stands must 
pay attention to the value of those who have an impact on the activities carried out by the hospital. So that every hospital operational activity will have an impact on the surrounding environment as well as the community. Thus, the responsibility of the Hospital to the surrounding community continues to be implemented. This was also said by Mr. DH in the Sanitation Installation section:

Mr. DH "If for the responsibility of the hospital is still limited to managing the environment properly, so there should be no hospital environmental waste that goes out to the surrounding environment, so before the waste is discharged to the water body, the quality of the liquid waste produced from the hospital is examined first".

The researchers' observations show that there is indeed no hospital waste that comes out of the environment of the surrounding community so that the hospital's efforts to account for it by protecting the environment so that it is not polluted within the community. This was also said by Ms. ES community around the hospital.

Ms. ES "For now the Bahteramas hospital is very good in protecting its environment so it does not have an impact on the surrounding community".

In social life, the Bahteramas hospital must also prioritize comfort for the community to achieve a sustainable society. This was also said by Ms. ES community around the hospital.

Ms. ES "The Bahteramas Hospital has given us comfort to the community around the hospital because as far as I know the Bahteramas Hospital is very caring for the environment so that it is not polluted, because in my opinion there are still many other hospitals that do not pay attention to the environment so as to make the surrounding community feel uncomfortable".

The results of observations by researchers that the Bahteramas Hospital always feels very responsible for the surrounding community to avoid pollution is seen from the cleaning staff who always clean the hospital environment.

Environmental audits are reviewed from the planet

The concept of environmentally friendly hospitals in hospitals is more directed at the use of water that is effective and efficient, the use of efficient electricity, and the management of liquid waste that is environmentally sound. On the other hand, the hospital must pay attention to good solid waste management and environmentally sound. Hospitals are required to participate in preserving the environment and the sustainability of biodiversity. Bahteramas Hospital has been proven capable of managing medical or nonmedical waste properly, this is evidenced by the management that collaborates with the Kendari city government in managing its waste so that it is more effective and efficient. This was also stated by Mr. DH in the Sanitation Installation section.

Mr. DH "For B3 medical waste, we provide treatment through the WWTP (Wastewater Treatment Installation) and for non B3 medical waste we only provide a temporary disposal site".

The results of observations by researchers that the Bahteramas hospital has indeed provided temporary shelters for non-medical waste while for medical waste the hospital has provided a special WWTP. This was also said by Ms. T in the Medical section.

Ms. T "As for the disposal of B3 waste, a special place has been provided, but for non-B3 waste it is temporarily accommodated because we are working with the city government so that we are transported by garbage disposal trucks and dumped to the Final Disposal Site every day".

The results of the researchers' observation that every day in the morning and evening the garbage truck will always come to take non-medical waste to be immediately disposed of in the landfill so that non-medical waste does not accumulate in temporary shelters provided by the hospital. Bahteramas Hospital in its waste management has cooperated with the Kendari City government related to the management of non-medical waste, with the cooperation the management can be more effective and efficient in the use of labor. Hospital actions in an effort to preserve the hospital environment so that it is better, healthier and more comfortable.

An environmental audit in terms of profit

The company in its activities is a must to pay attention to the impact produced in accordance with stakeholder theory that a company must report on hospital activities and social and environmental responsibilities to get support from its stakeholders for the company's sustainability. Efforts to deal with the environmental impacts that have been caused will certainly incur costs for the Hospital itself. Bahteramas Hospital has incurred costs 
to the environment. As said by Ms. $\mathrm{N}$ in Finance:

Ms. $\mathbf{N}$ "Regarding the allocation of funds for costs to the environment from the Hospital we have indeed provided, as for the expenditure of environmental costs related to the destruction of infectious waste by maintaining WWTPs and for positions on financial statements regarding environmental costs incurred are still under the burden of maintenance".

The results of observations by researchers that the Bahteramas hospital has tried to pay attention to their environment because there are already costs that they spend on the environment around the hospital so that it does not have a bad impact can be seen from the financial statements of the Bahteramas hospital, where for the position of the financial statements are still under the burden of maintenance, as for costs incurred by hospitals such as infectious waste and maintenance of WWTPs. Environmental audits play an important role in hospitals. As expressed by Mr. DH in the Sanitation Installation section.

Mr. DH "An environmental audit is very important to give awareness to both the community and officers so that they protect the environment.

The results of this interview explained that the importance of an environmental audit and also the hospital had conducted an environmental audit at the hospital. This was also said by Mr. DH in the Sanitation Installation section.

Mr. DH "An environmental audit is very necessary to maintain the environment around the hospital. And environmental audits are carried out every year".

To increase a sense of social and environmental responsibility and to increase accountability, companies should make reports, both reports containing narrative texts on activities and cost reports. At the Bahteramas hospital, the hospital had carried out a report on the hospital's activities. This is as said by Ms. $\mathrm{N}$ in the Finance section:

Ms. $\mathbf{N}$ "We report monthly to Regional Financial and Asset Management Agency, Inspectorate, and if we are audited by Audit Board of the Republic of Indonesia, we will provide the data to the Audit

Board of the Republic of Indonesia or Financial and Development Supervisory Agency, or other auditors who are in the hospital".

The implementation of environmental audits at Bahteramas Hospital has been carried out broadly and environmental audits incur costs on improving the surrounding environment so that the company remains sustainable, in the accounting department the Hospital has accommodated the activities carried out on the environment this can be seen in the financial statements where the position This is included in the maintenance burden of Rp. 2,053,035,431.00 (financial statements for 2018). The existence and sustainability of an entity is very much influenced by the support provided by stakeholders, because the entity in carrying out its activities is not only to fulfill its own interests and is only profit-oriented, but must pay attention to the benefits to its stakeholders.

Description of Results of the Implementation of Environmental Audit in Supporting Sustainability Development

Hospital is a form of hospital contribution and responsibility towards the social environment. Its application needs to be done considering the impact caused by the operation of the Hospital is very large. Hospitals, which are organizations that must be able to provide health insurance to the community, should properly control their waste which will have an impact on the spread of disease outbreaks. Creating a healthy environment should be one of the missions of organizations engaged in the health sector. The ability of hospitals to implement environmental audits is expected to be able to manage costs related to the environment and ultimately the hospital will be able to carry out sustainable development. As Mr. DH said in the Sanitation Installation section.

Mr. DH "The hospital should pay attention to these three things, namely the economy, environment and social affairs. So that we have a Public Health Community Hospital Counseling activity which is carried out every month and we surround each hospital building, to tell how to avoid using plastic, using detergent as economically as possible to avoid environmental pollution".

The three pillars are interrelated, if all three in the current generation are interrelated and support each other, then the results of the current generation will be enjoyed by the next generation. This was also said by Ms. N in the Finance section.

Ms. $\mathbf{N}$ "In addition to the economy, the company must also pay attention to the environment and the 
community because it will indirectly affect the environment and the community around the hospital, so from that we must pay attention to their environmental conditions, by making a program of activities to reduce the use of plastic. This has also been included in the improvement of the environment and surrounding communities, thus it can improve the image of the hospital so that profits from the company can be achieved".

The results of this interview explain that development can be achieved if development activities not only pursue economic interests, but also must pay attention to social or community and ecology or the environment. This goal is also shown to all stakeholders involved in hospital activities, both those directly involved and those not directly involved. Sustainability development can only be achieved if the hospital is able to harmonize the three elements namely environment, economy, and social, the ability of the hospital is expected to be able to manage costs related to the environment and in the end the company will be able to carry out sustainable development.

\section{Discussion}

Activities that have been carried out by the Bahteramas Hospital in an effort to preserve the environment have indeed incurred costs to the Hospital, but this will still be issued by the Hospital because it is an obligation for the Hospital to continue to maintain its environment in order to remain sustainable and active without damaging the environment, such is the case of environmental auditing required in a company as disclosure. Environmental preservation will be achieved by issuing costs related to the environment. this is also a form of accountability to stakeholders. Economic responsibility by producing maximum profits is also in accordance with the opinion of stakeholder theory which states that companies are not entities that only operate for their own interests but must provide benefits to their stakeholders. Stakeholder theory is a theory that says that the sustainability of a company is inseparable from the role of stakeholders both internal and external with a variety of different background interests of each of the existing stakeholders (Lindawati \& Puspita, 2015). The implementation of the environmental audit at the Bahteramas Hospital based on environmental activities carried out has incurred costs to the environment. The company has responsibility for the positive or negative impacts caused by economic, social and environmental aspects (Tarigan \& Samuel, 2014). With the triple bottom line, the approach is different, from the beginning the company has determined that the three holistic objectives namely Economic, Environmental and Social should be achieved in a balanced manner.

Table 1. List of Bahteramas Hospital environmental costs

\begin{tabular}{cl}
\hline No & \\
\hline 1 & Infection waste costs \\
2 & Medical equipment maintenance costs \\
3 & Medical equipment calibration costs \\
4 & Office and household equipment maintenance costs \\
5 & AC maintenance costs \\
6 & Radiological apparatus suitability test costs \\
7 & Radiology equipment operating permit fees \\
8 & Building maintenance costs \\
9 & Road maintenance costs \\
10 & Installation maintenance costs \\
11 & Network maintenance costs \\
12 & IPAL maintenance costs
\end{tabular}

Source: processed data, (2018)

Bahteramas Hospital in carrying out its production activities, of course, pay attention to environmental preservation. That is because companies must pay attention to the existing value system in the company must be balanced with the existing value system in society. The company's commitment to treat employees ethically and fairly, and provide fair compensation and this has been done by the Bahteramas Hospital by providing salaries in accordance with the compensation and the field occupied, and the hospital does not forget their responsibilities to the community around the hospital, by organizing a program of activities inviting the public to reduce the use of plastic. The program requires strong commitment, active participation, and sincerity from all concerned parties. The sustainable program is expected to be able to shape or create a more prosperous and 
independent community life. The activity carried out is indeed part of the company's commitment. It also revealed that a commitment must be carried out by a company to maintain its existence and as a feedback between the company and the environment and the community (stakeholders) within the company's territory.

Bahteramas Hospital must remain oriented to seek economic benefits that allow it to continue to operate and develop and still maintain its existence in supporting the sustainability of the hospital by achieving maximum profits without regard to other rights such as incurring costs to the environment and helping the community around the hospital. This Triple Bottom Line Theory directs companies to voluntarily contribute to create a better social life and a healthy environment (Muqodim \& Susilo, 2013).

Normatively, the management and use of the environment and natural resources must pay attention to environmental balance and the preservation of their functions and abilities. Utilization and management of the environment of natural resources is not only intended to be enjoyed in the present, but is also obliged to pay attention to the lives of future generations. So that in the management and utilization of the environment and its natural resources, it is appropriate to take action or prevent and control the negative impacts of development through the active participation of the parties as stakeholders in development. The sustainable development model is based on three main pillars of which three are interrelated, namely the first society, related to the role of the community, responsibility (responsibility) social interaction, community behavior and social conditions of the people in a region. The second environment, which is related to the natural environment, including the physical environment and the existence of a set of institutions as a result of man-made in the context of their use. The third economy, namely the economic welfare of the community and the use of the natural environment to meet the needs of the community, including in order to obtain benefits.

\section{Conclusions}

The results of the study found that the Bahteramas Hospital had the maximum in expressing costs to the environment in detail in the financial statement notes, but the costs incurred were still included in the maintenance burden category. The accounting practices that have been applied by Bahteramas Hospital have been maximized in implementing environmental audits. Activities that have been carried out by the company in terms of the environment, economy, and social aspects can already be said to support sustainable development.

\section{References}

Agustina, C. (2016). Perilaku Pemilik Atas Isu Manajemen Lingkungan Dilihat dari Sektor, regional dan Ukuran Perusahaan. Business Accounting Review, 4(1), 337-348.

Aminah, \& Noviani. (2014). Analisis Penerapan Akuntansi Lingkungan di Rumah Sakit Mardi Waluyo Metro. Jurnal Akuntansi \& Keuangan .

Astuti, A. D., \& Nugroho, P. I. (2016). Kepedulian Dan Pengetahuan Pelaku Bisnis Mengenai Green Accounting. Jurnal Analisis Bisnis Ekonomi, 14(1), 34-45.

Badjuri, A. (2011). Faktor-Faktor Fundamental, Mekanisme Corporate Governance, Pengungkapan Corporate Social Responsibility (CSR) Perusahaan Manufaktu dan Sumber Daya Alam di Indonesia. Dinamika Keuangan dan Perbankan. Vol 1 No. 1, pp.38-54.

Burhany, D. I. Nurniah. 2014.“Akuntansi Manajemen Lingkungan sebagai Alat Bantu untuk Meningkatkan Kinerja Lingkungan dalam Pembangunan Berkelanjutan”. Jurnal Simposium Nasional Akuntansi XVII, Lombok.

Deegan, C. (2004), Environmental disclosures and share prices-a discussion about efforts to study this relationship. In: Accounting Forum. Vol. 28. Australia: University of South Australia, School of Accounting and Information Systems. p87-97.

Du, X. (2018). A tale of two segmented markets in China: The informative value of corporate environmental information disclosure for foreign investors. The International Journal of Accounting, 53(2), 136-159.

Elkington, J. (1998), Partnerships from cannibals with forks: The triple bottom line of 21 st-century business. Environmental Quality Management, 8(1), 37-51.

Elkington, J. (2013), Enter the triple bottom line. In: The Triple Bottom Line. London: Routledge. p23-38. 
Ekwueme, C. M., Egbunike, C. F., \& Onyali, C. I. (2013). Benefits of triple bottom line disclosures on corporate performance: An exploratory study of corporate stakeholders. J. Mgmt. \& Sustainability, 3, 79.

Gray, R. (2010). A re-evaluation of social, environmental and sustainability accounting. Sustainability Accounting, Management and Policy Journal.

Harahap, N., Hardjono, W., \& Tarigan, K. (2016). Kaji Model Metode Penyuluhan Di Era Berlakunya Asean Economic Community (Aec) Melalui Sistim Penyuluhan Yang Bersinergi, Terintegrasi Dan Berkelanjutan. Jurnal Agrica Extensia, 10(1), 1122.

Hertwich, E.G. (2005), Consumption and the rebound effect: An industrial ecology perspective. Journal of Industrial Ecology, 9(1-2), 85-98.

Ja'far, M., \& Kartikasari, L. (2009). Need Assesments: Standar Akuntansi Carbon dan Praktik Carbon Accounting. In The 3rd National Conference (pp. 1-23).

Kosajan, V., Chang, M., Xiong, X., Feng, Y., Wang, S. (2018). The design and application of a government environmental information disclosure index in China. Journal of Cleaner Production, 202, 1192-1201.

Lindawati, A. S. L., \& Puspita, M. E. (2015). Corporate Social Responsibilty: Implikasi Stakeholder dan Legitimacy Gap dalam Peningkatan Kinerja Perusahaan. Jurnal Akuntansi Multiparadigma, 6(1), 157-174.

McCright, A.M., Dunlap, R.E. (2000), Challenging global warming as a social problem: An analysis of the conservative movement's counter- claims. Social Problems, 47(4), 499-522.

Mia, P., Al Mamun, A. (2011), Corporate Social Disclosure During the Global Financial Crisis. Malaysia Kelantan: Multimedia University.

Moleong, L. J. (2004). Metode kualitatif. Bandung: Remaja Rosdakarya.

Murdifin, I., Pelu, M. F. A., Perdana, A. A. H., Putra, K., Arumbarkah, A. M., Muslim, M., \& Rahmah, A. (2019). Environmental disclosure as corporate social responsibility: Evidence from the biggest nickel mining in Indonesia. International Journal of Energy Economics and Policy, 9(1), 115.

Muqodim, M., \& Susilo, J. (2013). Triple Bottom Line Reporting Dalam Pelaporan Tahunan Perusahaan Go Public Di Indonesia. Jurnal Akuntansi dan Auditing Indonesia, 17(1), 31-42.

Musyarofah, S. (2013). Analisis Penerapan Green Accounting di Kota Semarang (Doctoral dissertation, Universitas Negeri Semarang).

Neviana. (2010). Triple Bottom Line: Lebih dari Sekadar Profit, diakses di swa.co.id

Omer, A.M. (2008), Energy, environment and sustainable development. Renewable and Sustainable Energy Reviews, 12(9), 2265-2300.

Pettman, B., \& Herath, G. (2005). Sustainable development and environmental accounting: the challenge to the economics and accounting profession. International Journal of Social Economics.

Sari, M. P., \& Hadiprajitno, P. B. (2013). Pengawasan Impelementasi "Green Accounting" Berbasis University Social Responsibilities (Usr) Di Universitas Negeri Semarang Serta Studi Komparasi Universitas Se-kota Semarang. Jurnal Akuntansi dan Auditing, 9(2), 169-198.

Suartana, I. W. (2010). Akuntansi lingkungan dan triple bottom line accounting: Paradigma baru akuntansi bernilai tambah. Jurnal Bumi Lestari, 10(1), 105-112.

Widiawati, S., \& Raharja, S. (2012). Analisis Faktor-Faktor yang Mempengaruhi Islamic Social Reporting Perusahaan-Perusahaan Yang Terdapat Pada Daftar Efek Syariah Tahun 2009-2011 (Doctoral dissertation, Fakultas Ekonomika dan Bisnis).

Windasari, D. \& Herimurti. 2011. Pengelolaan Limbah B3 Medis Rumah Sakit Khusus di Surabaya Pusat dan Selatan.Institut Teknologi Sepuluh November

Tarigan, Josusa \& Hatane Samuel. 2014. Pengungkapan Sustainability Report dan Kinerja Keuangan. Jurnal Akuntansi dan Keuangan. 16 (2), 88-101

Yanti, F., \& Rasmini, N. K. (2015). Analisis Pengungkapan Triple Bottom Line dan Faktor yang Mempengaruhi: Studi di Perusahaan Indonesia dan Singapura. E-Jurnal Akuntansi Universitas Udayana, 13(2), 499-512.

York, R., Rosa, E.A. (2003), Key challenges to ecological modernization theory: Institutional efficacy, case study evidence, units of analysis, and the pace of eco-efficiency. Organization and Environment,16(3), 273-288. 